\title{
Tanggap Pertumbuhan Bibit Kakao (Theobroma cacao L.) Terhadap Berbagai Komposisi Media Tanam dan Frekuensi Penyiraman
}

Growth Response of Cocoa seed (Theobroma cacao L.) on various Growth Media Composition and Watering Frequency

\author{
Muhammad Yusnan Lubis, Rosita Sipayung*, Irsal \\ Program Studi Agroekoteknologi Fakultas Pertanian USU Medan 20155 \\ *Corresponding author :rosita_sipayung@yahoo.co.id
}

\begin{abstract}
Massive breeding is often the case with the availability of the amount of water that can be stored on the media. The aim of this research is to know the influence of media and frequency of watering to the growth of cacao seedlings and to find the best media and optimum watering frequency. This experiment was conducted at Agricultural Faculty of Agriculture, University of Sumatera Utara, Medan (32 $\mathrm{m}$ asl) from Juneuntil September 2017. The researchal method used was Factorial Randomized Block Design with two treatment factors. The first factor is growing media with four type, M0 (topsoil), M1 (topsoil: sand 2: 1), M2 (topsoil: rice husk 2: 1), and M3 (topsoil: rice husks charcoal 2: 1) and watering frequency: watered 1 (one) a day, watered every 4 (four) days, watered every 7 (seven) days, watered every10 (ten) days. The observed parameters were plant height, number of leaves, stem diameter, total leaf area, fresh shot weight, fresh root weight, shoot dry weight, dry root weight and root shoot ratio.The results showed that planting media treatment had significantly effect to plant height, number of leaves, fresh root weight, shoot dry weight and root dry weight. The best planting media treatment was found on topsoil (M0). Treatment of watering frequency did not significantly affect all observed variables. The interaction between the two treatments had a significantly effect on fresh root weight.
\end{abstract}

Keywords: growing media, frequency of watering, cocoa.

\begin{abstract}
ABSTRAK
Pembibitan yang dilakukan secara besar-besaran seringkali dijumpai masalah ketersediaan jumlah air yang dapat disimpan pada media. Penelitian bertujuan untuk mengetahui pengaruh media dan frekuensi penyiraman terhadap pertumbuhan bibit kakao dan mencari media terbaik serta frekuensi penyiraman yang optimum.Penelitian ini dilakukan di lahan pertanian Fakultas Pertanian, Universitas Sumatera Utara, Medan (32 mdpl) pada bulan Juni sampai September 2017. Metode percobaan yang digunakan adalah Rancangan Acak Kelompok (RAK) faktorial dengan 2 faktor perlakuan yaitu media tanam yakni M0 (topsoil), M1 (topsoil : pasir, 2 : 1), M2 (topsoil : sekam padi, $2: 1$ ), dan M3 (topsoil : arang sekam, $2: 1$ ) dan frekuensi penyiraman yakni 1 (satu) hari sekali, 4 (empat) hari sekali, 7(tujuh) hari sekali, dan 10 (sepuluh) hari sekali. Parameter yang diamati adalah tinggi tanaman, jumlah daun, diameter batang, total luas daun, bobot segar tajuk, bobot segar akar, bobot kering tajuk, bobot kering akar dan rasio tajuk akar. Hasil penelitian menunjukkan bahwa perlakuan media tanam berpengaruh nyata terhadap parameter amatan tinggi tanaman, jumlah daun, bobot segar akar, bobot kering tajuk dan bobot kering akar. Perlakuan media tanam terbaik terdapat pada topsoil (M0), Perlakuan frekuensi penyiraman tidak berpengaruh nyata pada semua parameter amatan. Interaksi antara kedua perlakuan berpengaruh nyata terhadap parameter amatan bobot segar akar.
\end{abstract}

Kata Kunci: media tanam, frekuensi penyiraman, kakao. 


\section{PENDAHULUAN}

Kakao (Theobroma cacao L.) merupakan salah satu komoditas perkebunan yang sesuai untuk perkebunan rakyat, karena tanaman ini dapat berbunga dan berbuah sepanjang tahun, sehingga dapat menjadi sumber pendapatan harian atau mingguan bagi pekebun.Tanaman kakao berasal dari daerah hutan hujan tropis di Amerika Selatan.Di daerah asalnya, kakao merupakan tanaman kecil di bagian bawah hutan hujan tropis dan tumbuh terlindung pohon-pohon yang besar (Widya, 2008).

Tanaman kakao diperkenalkan pertama kali di Indonesia pada tahun 1560, tepatnya di Sulawesi, Minahasa. Ekspor kakao diawali dari pelabuhan Manado ke Manila tahun 1825-1838 dengan jumlah 92 ton, setelah itu menurun karena adanya serangan hama. Hal ini yang membuat ekspor kakao terhenti setelah tahun 1928. Penanaman di Jawa mulai dilakukan tahun 1980 ditengah-tengah perkebunan kopi milik Belanda, karena tanaman kopi Arabika mengalami kerusakan akibat serangan penyakit karat daun (Hemileia vastatrix). Tahun 1888 puluhan semaian kakao jenis baru didatangkan dari Venezuela, namun yang bertahan hanya satu pohon.Biji-biji dari tanaman tersebut ditanam kembali dan menghasilkan tanaman yang sehat dengan buah dan biji yang besar.Tanaman tersebutlah yang menjadi cikal bakal kegiatan pemuliaan kakao diIndonesia (Karmawati et al., 2010).

Indonesia merupakan salah satu negara pembudidaya tanaman kakao paling luas di dunia dan termasuk Negara penghasil kakao terbesar ketiga setelah Ivory-Coast dan Ghana.Di Indonesia sendiri luas areal penanaman kakao mencapai 1.704 .982 ha dengan produksi pertahunnya mencapai 701.229 ton. Hampir 95\% dari total luasan lahan tersebut adalah perkebunan rakyat (Ditjenbun, 2015).

Untuk mendukung pengembangan tanaman kakao agar berhasil dengan baik, langkah awal usaha budidaya kakao yang baik adalah mempersiapkan bahan tanam di tempat pembibitan.Karena pembibitan merupakan pertumbuhan awal suatu tanaman sebagai penentu pertumbuhan selanjutnya maka pemeliharaan dalam pembibitan harus lebih intensif dan diperhatikan.Selain pemupukan, pertumbuhan bibit kakao juga dipengaruhi jenis tanah yang digunakan sebagai media (Syamsulbahri, 1996).

Pada pembibitan yang menggunakan polibag, kekurangan air merupakan masalah yang sering dihadapi, dimana tanaman akan mempunyai respon kekurangan air yang lebih besar dibanding tanaman yang ditanam di lapangan. Kakao merupakan tanaman yang rentan terhadap kekurangan air.Tanaman yang kekurangan air merupakan masalah yang paling utama pada tanaman yang masih muda karena lebih peka dibanding tanaman tua. Kekurangan air akan segera mengurangi kegiatan fotosintesis sehingga mengganggu produksi karbohidrat. Bila keadaan ini terus berlanjut akan menyebabkantanaman mati (Mildaerizanti dan Meilin, 2006).

Kekurangan air pada tanaman terjadi karena ketersediaan air dalam media tidak cukup dan transpirasi yang berlebihan atau kombinasi kedua faktor tersebut.Dilapangan, walaupun didalam tanah air cukup tersedia, tanaman dapat mengalami cekaman kekeringan (kekurangan air).Hal ini terjadi jika kecepatan absorsi tidak cukup mengimbangi kehilangan air melalui transpirasi(Fahmi, 2013).

\section{BAHAN DAN METODE}

Penelitian ini dilakukan di rumah kasa Fakultas Pertanian Universitas Sumatera Utara, Medan dengan ketinggian tempat \pm 32 meter di atas permukaan laut.Penelitian ini dilakukan pada bulan Juni sampai September 2017. Bahan yang digunakan dalam penelitian ini adalah benih kakao lindak ICS 13, polibagukuran $20 \mathrm{~cm} \times 30 \mathrm{~cm}$, komposisi media tanam: top soil, sekam padi, arang sekam, pasir, air,dan bahan-bahan lain yang mendukung penelitian ini.Alat yang digunakan dalam penelitian ini adalah cangkul, gembor, meteran, timbangan,oven,ember, beaker glass,pisau, 
pacak sampel, plang nama, kalkulator dan alat-alat lain yang mendukung penelitian ini.Rancangan yang dipergunakan dalam penelitian ini adalah Rancangan Acak Kelomposk(RAK) Faktorial yang terdiri dari 2 faktor perlakuan yaitu faktor I yaituMedia Tanam dengan 4 jenis perlakuan yaitu :top soil (M0), top soil : pasir 2:1 (M1), top soil : sekam padi 2:1 (M2), top soil : arang sekam 2:1 (M3). Faktor II yaitu Frekuensi Penyiraman dengan 4 taraf perlakuan, yaitu : disiram 1 hari sekali (F0), disiram 4 hari sekali (F1), disiram 7 hari sekali (F2), disiram 10 hari sekali (F3) dengan 3 kali ulangan. Data pengamatan dianalisis dengan sidik ragam pada taraf 5\%, jika berpengaruh nyata, dilakukan uji lanjutan dengan Uji Jarak Berganda Duncan.

Pelaksanaan penelitian dimulai dari persiapan lahan dengan dibersihkan dari gulma di areal tersebut dan diratakan, setelah dibersihkan, lahan diukur dengan ukuran seluas $2,8 \times 18,5 \mathrm{~m}$. selanjutnya dibuat naungan plastik setinggi $2 \mathrm{~m}$ dari permukaan tanah. Selanjutnya persiaan media tanam. Selanjutnya dilakukan persiapan media tanam dengan menggaunakan perbandingan volume sesuai dengan perlakuan yang ada.Setelah media tanam disiapkan selanjutnya dilakukan pindah tanam bibit ke polybag yang sudah diisi media tanam. Penyiraman tanaman diakukan pada pagi hari sesuai dengan taraf perlakuan yang telah ditentukan.Pemeliharaan tanaman meliputi penyiangan gulma dilakukan secara manual dengan mencabut gulma yang ada dalam plot tanaman, serta pengendalian hama penyakit.

Parameter yang diamati adalah tinggi tanaman, jumlah daun, diameter batang, total luas daun, bobot segar tajuk, bobot segar akar, bobot kering tajuk, bobot kering akar, dan rasio tajuk akar.

\section{HASIL DAN PEBAHASAN}

\section{Tinggi Tanaman}

Hasil sidik ragam menunjukan bahwa media tanam berpengaruh nyata terhadap parameter tinggi tanaman pada umur 2-12 MSPT.Perlakuan frekuensi peyiraman berpengaruh tidak nyata daninteraksi media tanam dan frekuensi penyiramanberpengaruh tidak nyata terhadap tinggi tanaman.

Pada Tabel 1 menunjukkan bahwa tinggi tanaman ada umur 2,4,6,8,10, dan 12 MSPT tertinggi diperoleh pada perlakuan M1 (media tanam top soil campur pasir) dan terendah dengan perlakuan M2 (media tanam topsoil campur sekam padi).

Pada perlakuan media tanam menunjukan tanaman kakao tertinggi pada umur 2-12 MSPT terdapat pada perlakuan M1 (media tanam topsoil campur pasir) dan terendah pada perlakuan M2 (media tanam topsoil campur sekam padi).Pada tanaman umur 2 sampai 6 MSPT perlakuan M1 (media tanam topsoil campur pasir) yang berbeda nyata dengan perlakuan M0 (media tanam topsoil), M2 (media tanam topsoil campur sekam), dan M3 (media tanam topsoil campur arang sekam). Pada tanaman umur 8 dan 10 MSPT perlakuan M1 (media tanam topsoil campur pasir) berbeda tidak nyata dengan perlakuan M0 (media tanam topsoil) tetapi berbeda nyata dengan perlakuan M2 (media tanam topsoil campur sekam) dan M3 (media tanam topsoil campur arang sekam).

Hal ini disebabkan pertumbuhan tanaman kakao membutuhkan air yang cukup untuk mendukung pertumbuhannya tetapi ketersediaan air tanah yang berlebih dapat mengganggu pertumbuhan tanaman. Media tanam topsoil campur pasir diduga baik karena memiliki aerasi yang baik tetapi ketersediaan airnya juga tidak berlebih. Hal ini sesuai dengan literatur Syamsulbahri, (1996) seperti tanaman pada umumnya, kakao juga menghendaki tanah yang mudah diterobos oleh akar tanaman, dapat menyimpan air terutama pada musim hujan drainase dan aerasinyabaik. 
Tabel 1. Rataan tinggi tanaman $(\mathrm{cm})$ kakao umur 2-12 MSPT pada perlakuan media tanam dan frekuensi penyiraman.

\begin{tabular}{|c|c|c|c|c|c|c|}
\hline \multirow[b]{2}{*}{ Umur } & \multirow[b]{2}{*}{ Media Tanam } & \multicolumn{4}{|c|}{ Frekuensi Penyiraman } & \multirow[b]{2}{*}{ Rataan } \\
\hline & & $\begin{array}{c}\text { F0 } \\
\text { (1 hari) }\end{array}$ & $\begin{array}{c}\text { F1 } \\
\text { (4 hari) }\end{array}$ & $\begin{array}{c}\mathrm{F} 2 \\
\text { (7 hari) }\end{array}$ & $\begin{array}{c}\text { F3 } \\
\text { (10 hari) }\end{array}$ & \\
\hline \multirow{5}{*}{2 MSPT } & M0 (Topsoil) & 22,32 & 23,89 & 23,99 & 23,81 & $23,50 \mathrm{~b}$ \\
\hline & M1 (Topsoil:Pasir) & 26,83 & 25,64 & 25,94 & 25,48 & $25,97 \mathrm{a}$ \\
\hline & M2 (Topsoil:Sekam) & 20,88 & 22,44 & 24,18 & 21,82 & $22,33 b$ \\
\hline & M3 (Topsoil:Arang Sekam) & 23,24 & 24,90 & 24,43 & 22,78 & $23,83 \mathrm{~b}$ \\
\hline & Rataan & 23,32 & 24,22 & 24,64 & 23,47 & 23,91 \\
\hline \multirow{5}{*}{4 MSPT } & M0 (Topsoil) & 23,63 & 24,20 & 24,58 & 25,69 & $24,52 b$ \\
\hline & M1 (Topsoil:Pasir) & 27,38 & 26,39 & 26,69 & 27,18 & $26,91 \mathrm{a}$ \\
\hline & M2 (Topsoil:Sekam) & 21,58 & 21,72 & 25,18 & 22,08 & $22,64 b$ \\
\hline & M3 (Topsoil:Arang Sekam) & 24,38 & 24,61 & 25,86 & 21,68 & $24,13 \mathrm{~b}$ \\
\hline & Rataan & 24,24 & 24,23 & 25,58 & 24,16 & 24,55 \\
\hline \multirow{5}{*}{$6 \mathrm{MSPT}$} & M0 (Topsoil) & 26,29 & 25,27 & 25,33 & 26,77 & $25,91 b$ \\
\hline & M1 (Topsoil:Pasir) & 30,08 & 28,22 & 27,56 & 28,13 & $28,49 a$ \\
\hline & M2 (Topsoil:Sekam) & 21,93 & 23,31 & 26,51 & 23,11 & $23,72 b$ \\
\hline & M3 (Topsoil:Arang Sekam) & 26,32 & 26,12 & 27,72 & 23,16 & $25,83 \mathrm{~b}$ \\
\hline & Rataan & 26,16 & 25,73 & 26,78 & 25,29 & 25,99 \\
\hline \multirow{5}{*}{$8 \mathrm{MSPT}$} & M0 (Topsoil) & 28,17 & 27,22 & 27,40 & 29,13 & $27,98 \mathrm{ab}$ \\
\hline & M1 (Topsoil:Pasir) & 31,34 & 29,36 & 29,88 & 29,10 & $29,92 \mathrm{a}$ \\
\hline & M2 (Topsoil:Sekam) & 24,14 & 24,48 & 28,25 & 23,72 & $25,15 c$ \\
\hline & M3 (Topsoil:Arang Sekam) & 28,66 & 27,08 & 28,69 & 22,91 & $26,83 \mathrm{bc}$ \\
\hline & Rataan & 28,08 & 27,03 & 28,55 & 26,22 & 27,47 \\
\hline \multirow{5}{*}{$10 \mathrm{MSPT}$} & M0 (Topsoil) & 30,44 & 29,74 & 28,61 & 31,92 & $30,18 \mathrm{ab}$ \\
\hline & M1 (Topsoil:Pasir) & 32,82 & 31,12 & 31,58 & 30,89 & $31,60 \mathrm{a}$ \\
\hline & M2 (Topsoil:Sekam) & 26,24 & 25,90 & 29,73 & 24,73 & $26,65 c$ \\
\hline & M3 (Topsoil:Arang Sekam) & 29,80 & 28,16 & 29,52 & 24,51 & $27,99 \mathrm{bc}$ \\
\hline & Rataan & 29,83 & 28,73 & 29,86 & 28,01 & 29,11 \\
\hline \multirow{5}{*}{$12 \mathrm{MSPT}$} & M0 (Topsoil) & 32,33 & 32,33 & 31,94 & 33,47 & $32,52 \mathrm{a}$ \\
\hline & M1 (Topsoil:Pasir) & 35,20 & 33,92 & 32,01 & 36,47 & $34,40 \mathrm{a}$ \\
\hline & M2 (Topsoil:Sekam) & 29,00 & 28,32 & 34,72 & 27,92 & $29,99 b$ \\
\hline & M3 (Topsoil:Arang Sekam) & 30,98 & 29,67 & 31,72 & 27,94 & $30,07 \mathrm{~b}$ \\
\hline & Rataan & 31,88 & 31,06 & 32,60 & 31,45 & 31,75 \\
\hline
\end{tabular}

Keterangan: Angka yang diikuti oleh huruf yang berbeda pada kolom yang sama adalah berbeda nyata berdasarkkan Uji Jarak Berganda Duncan pada taraf 5\%.

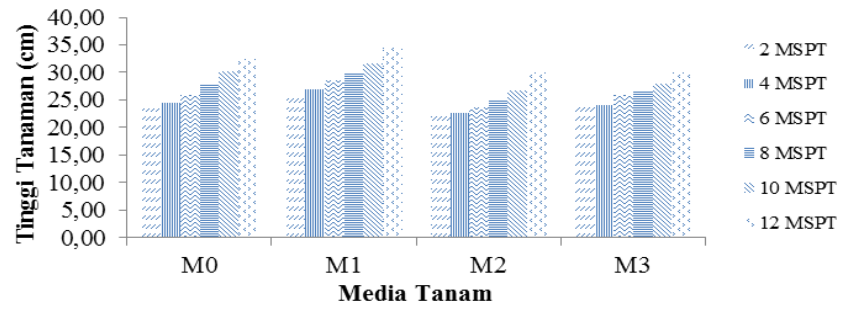

Gambar 1.Tinggi tanaman kakao pada berbagai media tanam. 
Tabel 2.Rataan jumlah daun (helai) tanaman kakao umur 2-12 MSPT pada perlakuan media tanam dan frekuensi penyiraman.

\begin{tabular}{|c|c|c|c|c|c|c|}
\hline \multirow[b]{2}{*}{ Umur } & \multirow[b]{2}{*}{ Media Tanam } & \multicolumn{4}{|c|}{ Frekuensi Penyiraman } & \multirow[b]{2}{*}{ Rataan } \\
\hline & & $\begin{array}{c}\text { F0 } \\
(1 \\
\text { hari) } \\
\end{array}$ & $\begin{array}{c}\text { F1 } \\
\text { (4 hari) }\end{array}$ & $\begin{array}{c}\mathrm{F} 2 \\
\text { (7 hari) }\end{array}$ & $\begin{array}{c}\text { F3 } \\
\text { (10 hari) }\end{array}$ & \\
\hline \multirow{5}{*}{2 MSPT } & M0 (Topsoil) & 9,89 & 10,33 & 10,00 & 10,44 & 10,17 \\
\hline & M1 (Topsoil:Pasir) & 11,00 & 10,11 & 9,89 & 10,67 & 10,42 \\
\hline & M2 (Topsoil:Sekam) & 9,44 & 9,56 & 10,89 & 11,11 & 10,25 \\
\hline & M3 (Topsoil:Arang Sekam) & 10,00 & 9,56 & 10,00 & 9,44 & 9,75 \\
\hline & Rataan & 10,08 & 9,89 & 10,19 & 10,42 & 10,15 \\
\hline \multirow{5}{*}{4 MSPT } & M0 (Topsoil) & 12,00 & 12,11 & 11,11 & 12,33 & $11,89 \mathrm{a}$ \\
\hline & M1 (Topsoil:Pasir) & 12,00 & 11,56 & 10,78 & 12,11 & $11,61 \mathrm{ab}$ \\
\hline & M2 (Topsoil:Sekam) & 9,78 & 9,89 & 11,67 & 12,56 & $10,97 b c$ \\
\hline & M3 (Topsoil:Arang Sekam) & 11,00 & 10,33 & 10,22 & 9,78 & $10,33 \mathrm{c}$ \\
\hline & Rataan & 11,19 & 10,97 & 10,94 & 11,69 & 11,20 \\
\hline \multirow{5}{*}{$6 \mathrm{MSPT}$} & M0 (Topsoil) & 12,11 & 12,22 & 11,78 & 12,67 & 12,19 \\
\hline & M1 (Topsoil:Pasir) & 13,22 & 12,56 & 11,89 & 12,89 & 12,64 \\
\hline & M2 (Topsoil:Sekam) & 10,56 & 11,44 & 12,00 & 14,11 & 12,03 \\
\hline & M3 (Topsoil:Arang Sekam) & 12,44 & 11,33 & 12,44 & 11,78 & 12,00 \\
\hline & Rataan & 12,08 & 11,89 & 12,03 & 12,86 & 12,22 \\
\hline \multirow{5}{*}{$8 \mathrm{MSPT}$} & M0 (Topsoil) & 14,33 & 14,67 & 13,67 & 14,33 & 14,25 \\
\hline & M1 (Topsoil:Pasir) & 14,67 & 13,22 & 13,67 & 13,67 & 13,81 \\
\hline & M2 (Topsoil:Sekam) & 12,89 & 12,56 & 14,83 & 14,78 & 13,76 \\
\hline & M3 (Topsoil:Arang Sekam) & 13,78 & 13,33 & 14,44 & 12,44 & 13,50 \\
\hline & Rataan & 13,92 & 13,44 & 14,15 & 13,81 & 13,83 \\
\hline \multirow{5}{*}{$10 \mathrm{MSPT}$} & M0 (Topsoil) & 16,56 & 17,11 & 15,56 & 16,22 & 16,36 \\
\hline & M1 (Topsoil:Pasir) & 16,22 & 14,11 & 15,78 & 14,33 & 15,11 \\
\hline & M2 (Topsoil:Sekam) & 15,33 & 13,44 & 17,67 & 15,44 & 15,47 \\
\hline & M3 (Topsoil:Arang Sekam) & 15,22 & 15,33 & 16,44 & 14,11 & 15,28 \\
\hline & Rataan & 15,83 & 15,00 & 16,36 & 15,03 & 15,56 \\
\hline \multirow{5}{*}{12 MSPT } & M0 (Topsoil) & 17,22 & 17,00 & 16,11 & 15,67 & 16,50 \\
\hline & M1 (Topsoil:Pasir) & 17,11 & 15,11 & 16,00 & 14,56 & 15,69 \\
\hline & M2 (Topsoil:Sekam) & 16,44 & 15,78 & 17,89 & 16,00 & 16,53 \\
\hline & M3 (Topsoil:Arang Sekam) & 16,56 & 15,89 & 15,56 & 15,33 & 15,83 \\
\hline & Rataan & 16,83 & 15,94 & 16,39 & 15,39 & 16,14 \\
\hline
\end{tabular}

Keterangan: Angka yang diikuti oleh huruf yang berbeda pada kolom yang sama adalah berbeda nyata berdasarkkan Uji Jarak Berganda Duncan pada $\alpha=0,05$. 


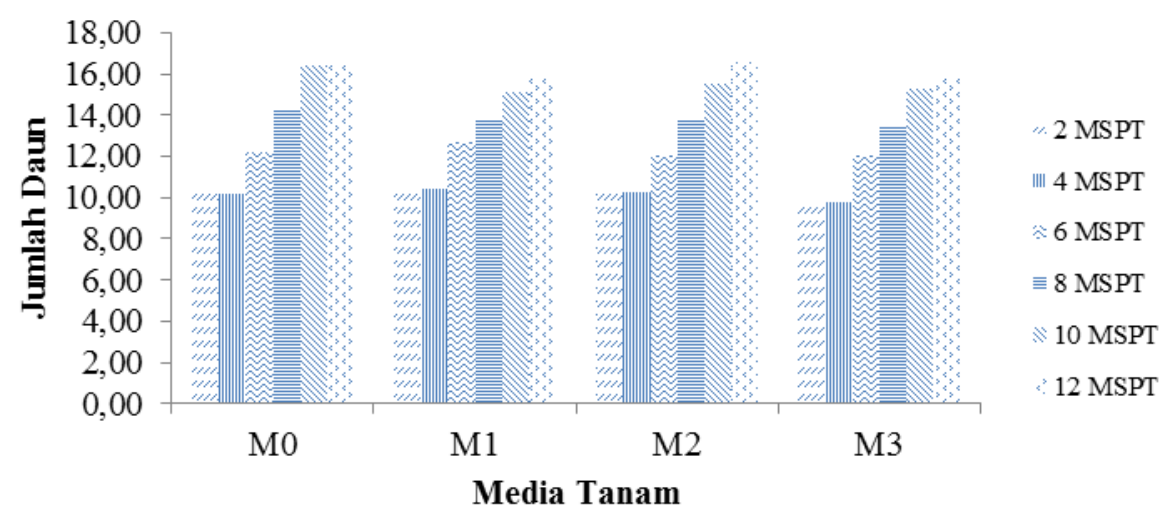

Gambar 2.Jumlah daun tanaman kakao pada berbagai media tanam.

\section{Jumlah Daun}

Perlakuan frekuensi peyiraman dan interaksi media tanam dan frekuensi penyiraman berpengaruh tidak nyata terhadap jumlah daun. Pada Tabel 2 menunjukkan bahwa jumlah daun pada umur 4 MSPT jumlah daun terbanyak diperoleh pada perlakuan M0 (media tanam topsoil) tidak berbeda nyata dengan perlakuan M1 (media tanam topsoil campur pasir) Tetapi berbeda nyata dengan perlakuan M2 (media tanam top soil campur sekam padi) dan M3 (media tanam top soil campur arang sekam).Perlakuan M1 (media tanam topsoil campur pasir) berbeda nyata dengan perlakuan M3 (media tanam topsoil campur arang sekam).Diduga hal ini disebabkan oleh nutrisi yang tersedia di dalam tanah masih cukup dan aerasi dari berbagai media tanam yang digunakan juga mendukung sehingga pertumbuhan tanaman optimal. Hal ini sesuai dengan literatur Sugiharyanto dan Khotimah (2009) yang menyatakan bahwa top soil merupakan lapisan horizon tanah yang bentuk lapisannya paling subur, berwarna cokelat kehitam-hitaman, gembur, dan memiliki ketebalan hingga $30 \mathrm{~cm}$.

\section{Bobot Segar Akar}

Hasil sidik ragam menunjukan bahwa perlakuan media tanam dan interaksi media tanam dan frekuensi penyiraman berpengaruh nyata terhadap parameter bobot segar akar tanaman. Perlakuan frekuensi peyiraman berpengaruh tidak nyata terhadap bobot segar tanaman.

Tabel 3. Rataan bobot segar akar (g) tanaman kakao pada perlakuan media tanam dan frekuensi penyiraman pada $12 \mathrm{MSPT}$.

\begin{tabular}{llllll}
\hline \multirow{2}{*}{\multicolumn{1}{c}{ Media Tanam }} & \multicolumn{5}{c}{ Frekuensi Penyiraman } \\
\cline { 2 - 5 } & $\begin{array}{c}\text { F0 } \\
(1 \mathrm{hari})\end{array}$ & $\begin{array}{c}\text { F1 } \\
(4 \mathrm{hari})\end{array}$ & $\begin{array}{c}\text { F2 } \\
(7 \mathrm{hari})\end{array}$ & $\begin{array}{c}\text { F3 } \\
(10 \mathrm{hari})\end{array}$ & Rataan \\
\hline M0 (Topsoil) & $4,81 \mathrm{~cd}$ & $6,58 \mathrm{ab}$ & $7,32 \mathrm{ab}$ & $7,96 \mathrm{a}$ & $6,67 \mathrm{a}$ \\
M1 (Topsoil:Pasir) & $6,17 \mathrm{bc}$ & $5,83 \mathrm{bcd}$ & $5,98 \mathrm{bcd}$ & $6,07 \mathrm{bcd}$ & $6,02 \mathrm{ab}$ \\
M2 (Topsoil:Sekam) & $5,78 \mathrm{bcd}$ & $4,51 \mathrm{~cd}$ & $6,97 \mathrm{ab}$ & $4,42 \mathrm{~d}$ & $5,42 \mathrm{ab}$ \\
M3 (Topsoil:Arang Sekam) & $4,92 \mathrm{~cd}$ & $4,84 \mathrm{~cd}$ & $4,84 \mathrm{~cd}$ & $5,95 \mathrm{bcd}$ & $5,14 \mathrm{~b}$ \\
\hline Rataan & 5,42 & 5,44 & 6,28 & 6,10 & 5,81 \\
\hline
\end{tabular}

Keterangan: Angka yang diikuti oleh huruf yang berbeda pada kolom yang sama adalah berbeda nyata berdasarkkan Uji Jarak Berganda Duncan pada $\alpha=0,05$. 
Gambar 3 dapat dilihat bahwa hubungan bobot segar akar dengan frekuensi penyiraman pada berbagai media tanam. Pada perlakuan M0 terdapat hubungan kuadratik positip dengan nilai maksimum bobot segar akar 8,00 gram dan frekuensi penyiraman (F) adalah 4,35 hari. Untuk perlakuan M1 dan M2 berlaku hubungan korelasi negatif, artinya semakin renggang jarak pemberian air semakin kecil bobot segar akar yang dihasilkan, sedangkan untuk perlakuan M3 terdapat hubungan kuadratik negatip dengan nilai minimum bobot segar akar 4,68 gram dan frekuensi penyiraman $(\mathrm{F})$ adalah 2 hari. Hal ini diduga disebabkan ketika dua perlakuan di kombinasikan akan menghasilkan kombinasi perlakuan dimana perlakuan media tanam topsoil (kontrol) dan diberi frekuensi penyiraman yang lebih lama akan menyebabkan perkembangan akar yang lebih baik. Hal ini sesuai dengan literatur Karmawati et al.(2010) kedalaman akar tunggang menembus tanah dipengaruhi keadaan air tanah dan struktur tanah. Pada tanah yang dalam dan berdrainase baik, akar kakao dewasa mencapai kedalaman 1,0 - 1,5 $\mathrm{m}$. Pertumbuhan akar kakao sangat peka pada hambatan, baik berupa batu, lapisa keras, maupun air tanah. Apabila selama pertumbuhan, akar menjumpai batu, akar tunggang akan membelah diri menjadi dua dan masing-masing tumbuh geosentris (mengarah ke dalam tanah).

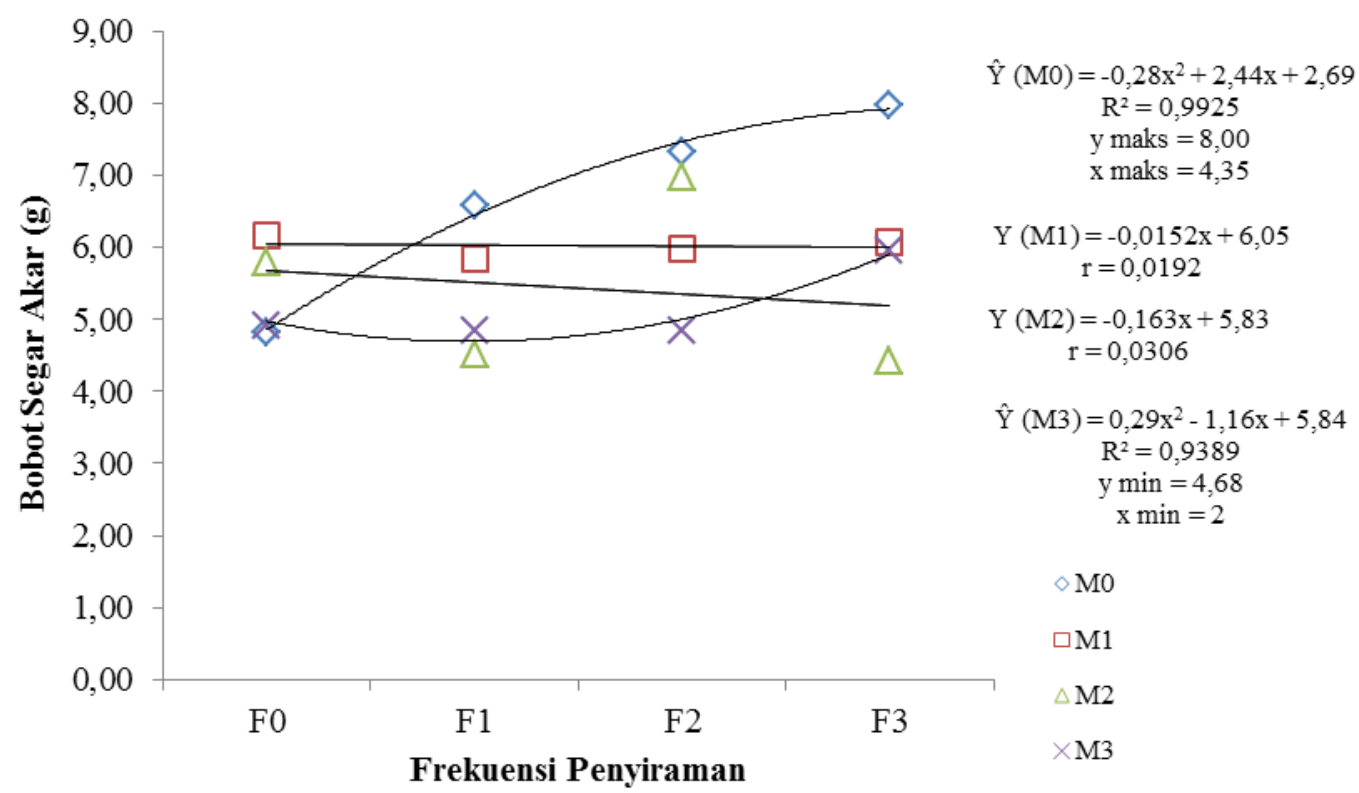

Gambar 3. Hubungan bobot segar akar tanaman kakao pada interaksi media tanam dan frekuensi penyiraman.

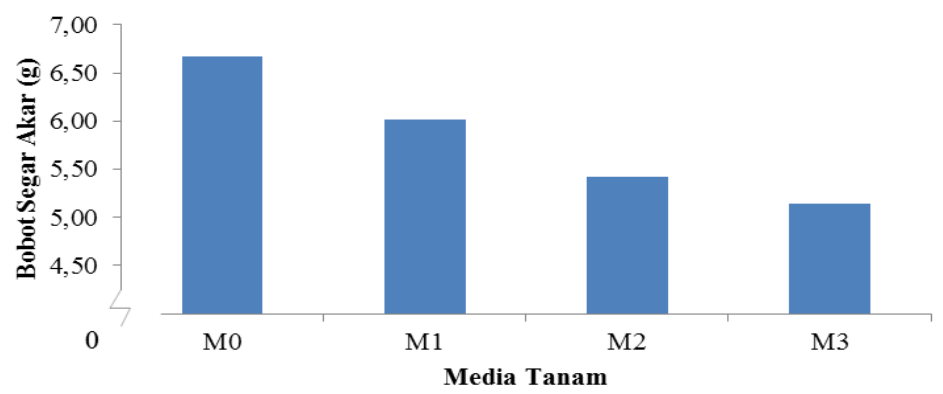

Gambar 4. Bobot segar akar tanaman kakao pada berbagai media tanam. 


\section{Bobot Kering Tajuk}

Pada Tabel 1 dapat dilihat bahwa perlakuan frekuensi peyiraman berpengaruh tidak nyata dan interaksi media tanam dan frekuensi penyiraman berpengaruh tidak nyata terhadap bobot kering tajuk tanaman dengan nilai tertinggi terdapat pada perlakuan frekuensi penyiraman 7 hari senilai 16,28 g

Pada Tabel 4 menunjukkan bahwa perlakuan M0 (media tanam topsoil) tidak berbeda nyata dengan perlakuan M1 (media tanam top soil campur pasir) tetapi berbeda nyata dengan perlakuanM2 (media tanam topsoil campur sekam) dan perlakuan M3(media tanam top soil campur arang sekam).

\section{Bobot Kering Akar}

Berdasarkan Tabel 5 dapat diketahui bahwa media tanam berpengaruh nyata terhadap penurunan parameter bobot kering akar tanaman dengan nilai tertinggi terdapat pada control senilai 10,32. Perlakuan frekuensi peyiraman dan interaksi media tanam dan frekuensi penyiramana berpengaruh tidak nyata terhadap bobot kering akar.

Tabel 5 tersebut menunjukkan bahwa perlakuan M0 (media tanam topsoil) berbeda nyata dengan perlakuan M1 (media tanam topsoil campur pasir), M2 (media tanam top soil campur sekam padi) dan M3 (media tanam top soil campur arang sekam). Diduga hal ini disebabkan oleh media tanam yang digunakan adalah topsoil yang berstruktur baik, sehingga penambahan media tanam lain seperti sekam padi dan arang sekam tidak menunjukkan pengaruh yang nyata terhadap diameter batang dan total luas daun tanaman.

Tabel 4.Rataan bobot kering tajuk (g) tanaman kakao pada perlakuan media tanam dan frekuensi penyiraman pada $12 \mathrm{MSPT}$.

\begin{tabular}{lccccc}
\hline & \multicolumn{5}{c}{ Frekuensi Penyiraman } \\
\cline { 2 - 5 } \multicolumn{1}{c}{ Media Tanam } & F0 & $\begin{array}{c}\text { F1 } \\
(4\end{array}$ & F2 & F3 & Rataan \\
& $(1$ hari $)$ & hari $)$ & $(7$ hari $)$ & $(10$ hari $)$ & \\
\hline M0 (Topsoil) & 16,22 & 17,36 & 18,59 & 18,73 & $17,72 \mathrm{a}$ \\
M1 (Topsoil:Pasir) & 18,78 & 16,65 & 17,74 & 16,29 & $17,36 \mathrm{a}$ \\
M2 (Topsoil:Sekam) & 12,50 & 13,16 & 16,25 & 14,38 & $14,07 \mathrm{~b}$ \\
M3 (Topsoil:Arang Sekam) & 15,29 & 12,86 & 12,53 & 12,08 & $13,19 \mathrm{~b}$ \\
\hline Rataan & 15,69 & 15,01 & 16,28 & 15,37 & 15,59 \\
\hline
\end{tabular}

Keterangan: Angka yang diikuti oleh huruf yang be rbeda pada kolom yang sama adalah berbeda nyata berdasarkkan Uji Jarak Berganda Duncan pada $\alpha=0,05$. 


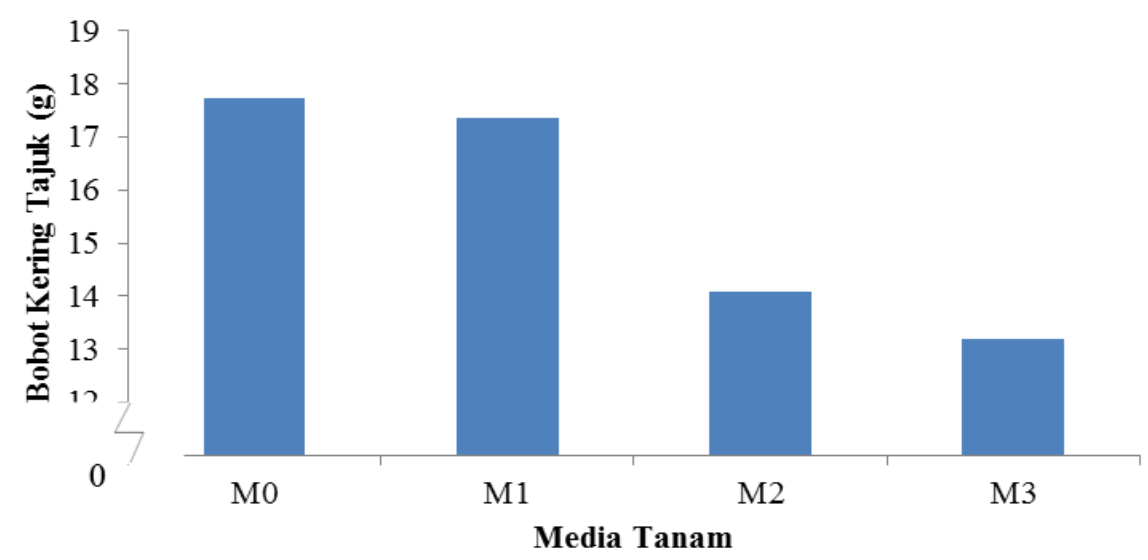

Gambar 5.Bobot kering tajuk tanaman kakao pada berbagai media tanam.

Tabel 5.Rataan bobot kering akar $(\mathrm{g})$ tanaman kakao pada perlakuan media tanam dan frekuensi penyiraman pada $12 \mathrm{MSPT}$.

\begin{tabular}{llllll}
\hline & \multicolumn{5}{c}{ Frekuensi Penyiraman } \\
\cline { 2 - 5 } Media Tanam & $\begin{array}{c}\text { F0 } \\
\text { (1 hari) }\end{array}$ & $\begin{array}{c}\text { F1 } \\
(4 \text { hari })\end{array}$ & $\begin{array}{c}\text { F2 } \\
(7 \text { hari })\end{array}$ & $\begin{array}{c}\text { F3 } \\
\text { hari })\end{array}$ & \\
\hline M0 (Topsoil) & 8,42 & 10,48 & 11,02 & 11,38 & $10,32 \mathrm{a}$ \\
M1 (Topsoil:Pasir) & 9,13 & 8,54 & 9,03 & 8,96 & $8,91 \mathrm{~b}$ \\
M2 (Topsoil:Sekam) & 7,58 & 5,84 & 9,64 & 7,56 & $7,65 \mathrm{~b}$ \\
M3 (Topsoil:Arang Sekam) & 7,03 & 6,85 & 7,15 & 9,32 & $7,59 \mathrm{~b}$ \\
\hline Rataan & 8,04 & 7,96 & 9,21 & 9,31 & 7,65 \\
\hline
\end{tabular}

Keterangan: Angka yang diikuti oleh huruf yang berbeda pada kolom yang sama adalah berbeda nyata berdasarkkan Uji Jarak Berganda Duncan pada $\alpha=0,05$.

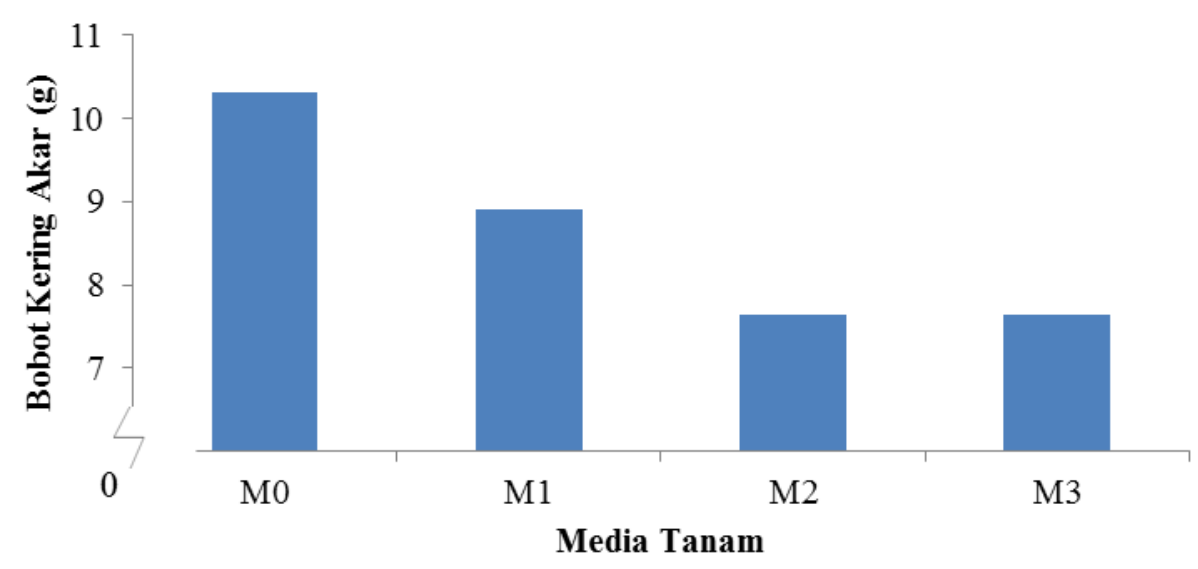

Gambar 6.Bobot kering akar tanaman kakao pada berbagai media tanam.

Hal ini didukung dengan literatur Hidayat et al.(2007), yang menyatakan bahwa topsoilmerupakan lapisan tanah atas yang mengandung bahan organik, berwarna gelap dan subur yang memiliki ketebalan sampai 25 $\mathrm{cm}$. 


\section{SIMPULAN}

Media tanam berpengaruh nyata dalam meningkatkan tinggi tanaman, jumlah daun, bobot segar akar, bobot kering tajuk, dan bobot kering akar. Tetapi berpengaruh tidak nyata dalam meningkatkan total luas daun, bobot segar tajuk dan rasio tajuk akar tanaman kakao.Hasil terbaik diperoleh pada penggunaan media tanam topsoil. Sedangkan frekuensi penyiraman tidak berpengaruh nyata pada semua parameter. Serta interaksi antar keduanya berpengaruh nyata pada bobot segar akar dengan penyiraman terbaik pada perlakuan M0F3 media tanam topsoil dan frekuensi penyiraman 10 hari.

\section{DAFTAR PUSTAKA.}

Ditjenbun. 2015. Statistic perkebunan Indonesia komiditas kakao 2013-2015. Jakarta

Fahmi, I. Z. 2013. Media Tanam Sebagai Faktor Eksternal Yang Mempengaruhi Pertumbuhan Tanaman. Balai Besar Perbenihan dan Proteksi Tanaman Perkebunan. Surabaya.

Hidayat, T. C., G. Simangsunsong, Eka Listia I. dan Y. Harahap. 2007.Pemanfaatan Berbagai Limbah Pertanian untuk Pembenah Media Tanam Bibit Kelapa Sawit. Jurnal Penelitian Kelapa Sawit, 15 (2) hal 185-193

Karmawati, Elna. Zainal, Mahmud. M. Syakir, S. Joni, Munarso. I Ketut, Ardana.Rubiyo. 2010. Budidaya dan Pasca Panen Kakao. Pusat Peneitian dan Pengembangan Perkebunan

Mildaerizanti dan Meilin, A., 2006. Penggunaan Mulsa Organik Pada Pembibitan Kakao Dalam Polybag, Balai Pengkajian teknologi Pertanian Jambi (BPTP) Jambi, Jambi.http://katalog.pustakadeptan.go.

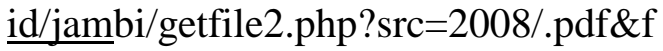
ormat=application/pdf. Februari2017).

Sugiharyanto dan N. Khotimah. 2009. Diktat Mata Kuliag Geografi Tanah.
Universitas Negeri Yogyakarta.

Yogyakarta.

Syamsulbahri, 1996, Bercocok Tanam Perkebunan Tahunan.UGM Press.Yogyakarta.

Wahyudi, T., T, R, Panggabean., dan Pujianto, 2008. Panduan Lengkap Kakao manajemen Agribisnis dari Hulu ke Hilir. Penebar Swadaya. Jakarta.

Widya.Y., 2008, Budidaya bertanam Cokelat, Tim Bina karya Tani, Bandung. 